\title{
A világrendszer-elmélet alapjai
}

\author{
Immanuel Wallerstein Bevezetés a világrendszer-elméletbe ${ }^{1}$ \\ címü könyvének bemutatása
}

\section{The Basics of World-system Theory \\ Book review of Immanuel Wallerstein's \\ World-system analysis: An Introduction}

\begin{abstract}
A társadalomtudományok egyik legmeghatározóbb alakja Immanuel Wallerstein, akinek úgy életpályája, mint újszerủ elméleti megközelítései új fénybe helyezték a világról alkotott képünket gazdasági, társadalmi és kulturális téren egyaránt. Az elemzés tárgyát képező könyv hasábjain a világrendszer-elmélet legfőbb pilléreinek azonosítására, bemutatására és a legmeghatározóbb elemei közötti kapcsolatok feltérképezésére kerül sor. A világunkban észlelt realitások feltárása által ma már egyértelmú és vitathatatlan tényként kezelendő, hogy minden időszakos változások áldozataként fogható fel, és ezen valóságok egy láthatatlan hálózatként egymás összefüggéseinek eredményeképpen múködnek.
\end{abstract}

\section{A mú aktualitása}

Mai világunk meghatározó és kikerülhetetlen fogalmakként kezeli, úgy a mindennapi szóhasználatban, mint a tudományos életben, a globalizáció és a terrorizmus kifejezéseket, de ezt sok esetben követi a kapitalizmus, tôke, piacgazdaság, politikai ideológiák, technológia, munka stb. fogalmak kimeríthetetlen összessége. Valójában mit fednek ezek a fogalmak? Hol kapcsolódnak egymáshoz? Milyen gyökerük, történetiségük van? Mennyiben határozzák meg a világ alakulásának a dolgait, és a hétköznapi emberre milyen valós hatással vannak? Ezek történeti és jelenkori vizsgálata tudna pontos képet alkotni számunkra a jövőre nézve? Mindezek ismeretében tudjuk azonosítani és korrigálni a társadalomban

Kocsis Lóránt Zsombor a Nemzeti Közszolgálati Egyetem másodéves doktoranduszhallgatója, a Marosvásárhelyi Református Kollégium közgazdaságtanára. E-mail: kocsis.lorant@yahoo.com A szerző 2010-ben magyar nyelvre fordított és a L’Harmattan Kiadó által kiadott könyve. 
jelentkező hibákat? A fenti kérdések a mai kor legégetőbb problémáira világítanak rá, amelyeket Wallerstein müvében elemez.

Joggal merülhetnek fel azonban kételyek, hogy az akkor megfogalmazott megállapítások, nézetek mennyire állják meg helyüket az aktualitás talaján. Elsődlegesen fontos kiemelni, hogy a mü jelentős része történeti visszatekintést tartalmaz és bizonyos tudományok, események, ideológiák történelmi gyökereit vizsgálja, illetve fogalmaz meg megállapításokat ezekkel kapcsolatban, az objektív módon és valós adatokkal alátámasztott történelmi események pedig az idő múlásával nem változnak. Ugyanakkor nem kerülheti el figyelmünket, hogy Wallerstein elméletei nem korlátozódtak az akkori jelen határai közé, hiszen az általa képviselt szemléletek történelmi időléptékkel mérendők, nem pedig naptári években. A történelmi időlépték ugyanis, Braudel kifejezésével élve, longue durée, egyenlő egy adott történelmi rendszer teljes életciklusával. (Wallerstein, 2010) Azon rendszer életciklusa pedig, amelyben az író élt, alkotott és megfogalmazta a müben megjelenő nézeteket, elméleteket, ma is tart, ez a kapitalista berendezkedésben ölt testet, ami bár több szempontból is válságban van, végének megjelölése pontatlan jóslatokban merülne ki. Nézzük az időszerúség állításának valóságalapját. Ami a gazdaság világszintű mechanizmusát illeti, a tengelyszerű munkamegosztást tartja mérvadónak, amelyet a centrum-periféria viszony keretén belül fejez ki. A centrumból, ahol a legfejlettebb országok találhatók, a munkaerő költségcsökkentése miatt a termelőegységek létesítése a periférián, elmaradott országokban valósul meg, és mindez ciklikusan történik. ${ }^{2}$ Ennek hatásaként a gazdasági fejlettségi szint következtében létrejövő szakadék, a fejlett és elmaradott országok között, megmarad és tovább mélyül. Mivel az akkor elemzett történelmi időlépték ma is tart, ez a felosztás és megállapítás időszerű. Ezt kortárs szaktekintélyek is elismerik, a változás abban figyelhető meg, bár ez az elmélet lényegén nem változtat, hogy a technológia fejlődésének köszönhetően, a centrumban az újítások szinte folyamatosak, és ahogy megjelennek, szinte azonnal megtörténik a termelés kiszervezése a periféria irányába, aminek következtében megszilárdul a centrum-periféria viszony országokra vetített szereposztása. (Artner, 2014)

Wallerstein kitér az állam fogalmára is, az állam-vállalat viszonyára, illetve a hegemónia kérdéskörére. Az akkori megállapítások azóta sem változtak, például a vállalatok költségeinek externalizálása (szennyezés, szállítás stb.), amelyek az államok költségvetését terhelik, bizonyos esetekben a jelen pillanatban is ugyanúgy, ugyanabban a formában megfigyelhetők. Időszerű megállapítás az is, hogy világbirodalmak már nem léteznek, helyettük az erős állam szerepköre a hegemón státuszban testesül meg. Ennek értelmében nem egy politikai autoritás uralkodik, hanem az államközi kapcsolatok hálózatában a legerősebb irányítja a világgazdaságot és érvényesíti politikai akaratát (például Egyesült Államok).

A politikai ideológiák és társadalmi osztályok ${ }^{3}$ ebben a pillanatban is a könyv által megfogalmazott formában léteznek, sőt az azóta kiélesedő globális szintű konfliktusok (társadalmi rétegek, vallási nézetek stb. között) gyökerei is ide vezethetők vissza.

A múben megjelenő, az unidiszciplinaritás szemléletét megfogalmazó elméletet illetően azóta még inkább világossá vált, hogy a társadalomtudományok közötti

Ezen elméletet a továbbiakban részletesen kifejti a szerző.

Státusz- és identitáscsoportok. 
választófalak lebontása, az átjárhatóság biztosítása, mindezek egy egészet alkotó diszciplínaként való kezelése eredményesebb keretet biztosít bizonyos problémák elemzését és hatékony megoldását illetően.

\section{Szerkezeti felépítés, elemzés}

Wallerstein ezen múvében foglalja össze az általa fémjelzett eszmerendszer történetét és főbb állításait. Mindez a következő tartópilléreken nyugszik: tudományos keret, modern állam, kapitalizmus, geokultúra és a világrendszer válsága. A tudományos feltérképezésnél két alapvető tudományterület szembeállítása figyelhető meg, mindkettő jellegzetességének kimerítésével, ezek a természettudományok (empirikus, szcientista felfogás) és a humanisztikus interpretáció. A gazdaságtudományok esetében két elmélet között mozgott a mérleg nyelve: a leíró jellegű fejlődés-gazdaságtan és a matematikán alapuló formalizálás, absztrakt modellezés gazdaságtana. Végül a neoliberális és neoklasszikus nézetek győzelmének köszönhetően az utóbbi elmélet vált dominánssá. (Gilpin, 2004) A két fő, klasszikus értelemben vett tudományterület még felveti az idiografikus és a nomotetikus fogalmak közötti különbség fontosságát is. Az előző egyéni rajzolásút jelent, azaz minden eseményt külön a maga partikularitásában kell vizsgálni, ez a humanisztikus megközelítés eszköze és az utóbbi a törvényszerűsítésre törekszik, mint a szcientizmus alapköve. Mindezek tisztázása azért elengedhetetlen, mert Wallerstein világrendszer-elmélete egy olyan, még mai értelemben is újfajta megközelítést tár elénk, ami az unidiszciplinaritásban ölt testet. (Wallerstein, 2010) A fogalom nem összetévesztendő a multidiszciplinaritással vagy a diszciplínák közöttiséggel, hiszen a szerző megközelítésében nincs értelme a társadalomtudomány különböző ágazatait szétválasztani, hanem a „határok lebontásával” egységes diszciplínaként kell kezelni, mert csak ekkor lelhetők fel azok az összefüggések, amelyek elmélete lényegét képezik. A fent említett megközelítés természetesen nem kerülte el a kritikusok figyelmét sem. Robert Brenner, a marxisták táborának képviseletében azt kifogásolta, hogy a világrendszerelmélet túlzottan nagy figyelmet szentel a piaci tényezőknek (árucsere), és figyelmen kívül hagyja a proletariátus szerepét, illetve nem veszi figyelembe a társadalomban fellelhető osztálykülönbségeket. Theda Skocpol és Aristide Zolberg Otto Hintze munkáira alapoznak. Ellenérvük, hogy az állami és államközi viszonyok jelentősége háttérbe szorul a kapitalista világgazdaság javára, és ebből vezetődnek le bizonyos tézisek. Végül pedig Stanley Aronowitz szerint az elemzett elmélet figyelmen kívül hagyja a kulturális szféra centrális és autonóm valóságát és túlzottan a gazdasági levezetésekre helyezi a hangsúlyt. (Wallerstein, 2010) Valójában mindegyik kritikai megközelítés azt kifogásolja, hogy a világrendszer-elmélet nem helyezi középpontba az általa képviselt ideológiát, szemléletet. Ennek igazságtartalma vitathatatlan, viszont ez nem elegendő egy biztos alapokon nyugvó kritikai szerkezet felállításához, és mindez az említett kritikusok szúklátókörűségét bizonyítja. A világrendszer-elmélet egyetlen kijelentésében sem kifogásolja a kvantifikáció fontosságát, mindössze fenntartja a narratizmus jelentőségét is, és a rá jellemző módon óvakodik a szélsőségektől, ezért figyelembe veszi mindkettőt. Az osztálykülönbségekről tett kijelentés több mint megalapozatlan, hiszen a szerző külön alfejezetként tárgyalja a státuszcsoportok, identitáscsoportok és osztálykülönbségek jelentőségét, 
ezáltal elismerve, hogy mindezeknek kiemelkedő fontosságuk és szerepük van. Az elmélet elemzésének hiányosságát bizonyítja az állami és kulturális kritikai megközelítés is, hiszen az állam, államközi viszonyok, illetve kulturális tényezők alkotóelemei az elméletnek. Továbbá művében Wallerstein négy olyan fő mozzanatot jelöl meg, amelyek jelentősen befolyásolták és előkészítették a terepet a világrendszer-elmélet számára. (Wiener, 2011) Ezek a következők: a centrum-periféria viszony (ezt lentebb részletesen elemezzük), az „ázsiai termelési mód” (azokra a társadalmakra utal, amelyek kirekedtek, kívül maradtak a világtörténelmi fejlődés fő vonalán), átmenet a feudalizmusból a kapitalizmusba (a külső és belső befolyásoló tényezők vitája) és a „totális történelem” kérdése, majd az Annales iskola (a történelem tágabb megközelítése). A kor, amelyben ma élünk, Wallerstein megfogalmazása szerint a „modern” világrendszer világa, amely valójában egy kapitalista világgazdaság. Ennek első és legfontosabb ismertetőjele a tőke vég nélküli felhalmozása. (Wallerstein, 2010) A világgazdasági rendszert az ember hozta létre és uralja. Látszólag. Meglátásom szerint feltehető a kérdés, mi van akkor, ha a tőke, mint a kapitalizmus lényege, mindent átható, átszövő valósága olyan törvényszerűségeket generál, amelyek már a tőke fennmaradási, sőt halmozódási érdekeit veszik figyelembe, nem pedig a társadalom és ezen belül az ember alapvető érdekeit? Egy rendszer, amelyet az ember hozott létre, a meghatározott irányvonalak mentén, tehetetlenségi erejéból egy olyan entitást alkotott, amely az idő múlásával szinte észrevétlenül kivette az ember kezéből az irányítást, és megalkotója fölé emelkedve, ennek irányítójává vált. Nevezhetnénk ezt akár a tôke diktatúrájának is. Ami a piacokat illeti, egy látszólagos paradoxonnal állunk szemben, hiszen a kapitalizmus hívei, a szakirodalom és a tankönyvek is a szabadpiacról beszélnek, és úgy tüntetik fel, hogy ez a kapitalizmus egyik alapfeltétele. Ez a nézőpont viszont téves. A valóságban teljesen szabad piac nem jöhet létre, hiszen ez ellehetetlenítené a tőke vég nélküli felhalmozását. Képzeljünk el egy olyan gazdasági környezetet, ahol a termelési tényezők akadálymentesen mozognak, mindenki informált, és nagyszámú vevővel nagyszámú eladó áll szemben. Ez a keret a tökéletes verseny megvalósulását jelentené, ami köztudottan a valóságban nem létezik, de a tőkések nemhogy a tökéletes piaci feltételeket nem szeretik, hanem egyáltalán magát a versenyt sem. Ez pedig szorosan összefügg a profitrátával. Minél inkább kiváltságossá válik egy vállalat egy új termék bevezetése során, annál kisebb lesz a versenyhelyzete és annál nagyobb értéktöbblettel tudja eladni termékeit. Ennek következtében jelentősen megnő az eladási ár és a termelési költség közötti különbség, ami a profitráta egyértelmű növekedéséhez vezet. Ezért a mostani gazdasági berendezkedésben nemhogy szabadpiacról nem beszélhetünk, hanem megfigyelhető a kvázimonopóliumok megjelenése. Monopóliumok (egyetlen eladó létezik), nagyon nehezen hozhatók létre, ezért inkább úgynevezett kvázimonopóliumok (néhány eladó), jönnek létre, amit gazdasági szakkifejezéssel oligopóliumtípusú versenynek nevezünk. Ezen kvázimonopóliumok viszont meglehetősen rövid életűek, de eléggé sokáig képesek fennmaradni (akár több évtizedig is), ahhoz, hogy jelentős tőkefelhalmozást valósítsanak meg. Attól a pillanattól kezdve, hogy egy piac kezd kompetitívvé (versenyhelyzetúvé) válni, a kiváltság, ami a nagy profitrátában ölt testet, egyre csökken, hiszen elkezdenek csökkenni az árak is, ezáltal csökken az eladási ár és a termelési költség közötti különbség is. Ekkor a tőketulajdonosok más vezértermékekbe vagy új vezető (cutting edge) iparágakba kezdenek befektetni, ami elölről kezdi a folyamatot, újabb kvázimonopóliumok kialakulását eredményezve, így a játék 
soha nem ér véget. (Wallerstein, 2010) Az elmélet egyik legalapvetőbb mérföldköve a tengelyszerű munkamegosztás, amely a termelést centrumra és perifériára osztja fel. A centrumban azonosíthatjuk a legerősebb gazdasággal rendelkező államokat (Egyesült Államok, Németország, Egyesült Királyság, Japán stb.), az ellenkező póluson, a periférián pedig a legkiszolgáltatottabb államokat (Ázsia, Afrika jelentős részei). Megfigyelhető ugyanakkor egy átmenet is a két pólus között, amelyet félperifériás államoknak neveznek (például Közép-Kelet Európa, Dél-Korea, Brazília, India stb.). Mivel az erőviszonyok eltérőek, egyértelműsíthető, hogy értéktöbblet-áramlás vagy akár elszivattyúzás történik a perifériából a centrum felé. A világgazdaság ciklikus változása is ennek köszönhető. Amikor a centrumban megjelenik egy vezető iparág, és ennek következtében kialakulnak a kvázi-monopóliumok, akkor expanzióról beszélünk, és megkezdődik a tőke felhalmozása. Ebben az esetben nő a foglalkoztatottság, növekednek a bérek, óriási profitráták jellemzőek, és egy általános prosperitás figyelhető meg. Idővel viszont, ahogy egyre több vállalat lép be a kvázimonopol térbe, egyre inkább felhígul ez a környezet, és a piac egyre kompetitívebbé válik. Ez a versenyhelyzet azt eredményezi, hogy túltermelés alakul ki, felhalmozódnak az eladatlan termékek, illetve zuhanásba kezd a profitráta. Ebben a pontban a gazdaság növekedési görbéje átfordul, és belépünk a recesszió időszakába. (Wallerstein, 2010) Mivel a vállalatok költségeik csökkentésére vannak kényszerítve, hogy az árbevétel és termelési költség közötti rés ne zsugorodjon tovább, az olcsóbb munkaerő irányába fordítják figyelmüket, ezáltal centrifugális erők lépnek müködésbe, és elkezdődnek a termelési folyamatok kiáramlásai a centrumból a periféria irányába, amelyek beruházások által valósulnak meg. A beruházások két típusát különböztetjük meg: a portfólióberuházást (gyors pénzszerzés) és az FDI hosszú távú beruházásokat. (Gilpin, 2004) Általában ezek elsődleges élvezői a félperifériás államok, majd idővel tovább sodródnak a perifériás országokba. Ennek a folyamatnak köszönhetően lassan a bérek a centrumban is süllyedni kezdenek, és a termékek iránti kereslet, amely eddig a túltermelés miatt volt elégtelen, most a lenyomott bérek miatt tovább zuhan. Ilyen helyzetben az egyik bevált módszer a centrumban való bérek emelése, ami visszaállítja a kereslet szintjét, és új vezértermékek értékesítését teszi lehetővé. Amennyiben ez megvalósul, a recesszió görbéje visszakanyarodik, és újabb expanzió jöhet létre. Ez egy koordináta-rendszerben is ábrázolható, ahol A fázis az expanzió és B fázis a pangás vagy recesszió. Az A és a rákövetkező B fázist Kondratyev-ciklusnak szokták nevezni. Ez a világgazdaság szisztolé-diasztoléja. A világgazdaság történeti megfigyelése alapján a Kondratyev-ciklusok hossza általában ötven-hatvan év volt, de ez nagy mértékben attól függ, hogy egyes államok milyen politikai és intervencionista lépéseket tesznek a B fázis elkerülése és, ami talán még ennél is fontosabb, az ebből való kilábalás végett. A kapitalizmus globalizációs jellegének köszönhetően a Kondratyev-ciklus a két szakasz (extenzív és intenzív) térben szét-, időben pedig összecsúszását eredményezte. Ami azt jelenti, hogy a centrumban az újítások szinte folyamatosak (intenzív szakasz), és röviddel az új technológia bevezetése után már az alacsonyabb bérszintű régiók felé telepednek (extenzív szakasz), egyre nagyobb területeket lefedve. Mindez, ahogy már fentebb megállapításra került, egyre inkább megszilárdítja a centrum-periféria országokra vetített szereposztását. A perifériás országoknak alulfejlettek a termelőalapjaik, ezért beleragadnak a tőkemegtérülési ciklus extenzív szakaszába. (Wallerstein, 2010) A szerző a centrum-periféria viszony elméletében azonban, amikor a bérek 
csökkenéséről értekezik, nem tér ki néhány társadalomban fellelhető realitásra. Ilyenek a szakszervezetek szerepvállalása ebben a kérdéskörben, az állami jogrendszer a bérek tekintetében vagy az alkalmazó-alkalmazott szerződéses kereteire, és hogy ezek mekkora teret engednek a bérek ingadozásának. A világgazdaság-elméletre azonban jellemző, amint már az előző oldalakon szó esett róla, hogy összeköt, és kilépve a diszciplináris „dobozokból”, egy nagyobb hálózati egység egészét szemlélve vizsgálja a társadalmi valóságokat. Ezért a már részben elemzett politikai, történelmi és gazdasági területek mellett bevonja a háztartások és ezek jövedelmének vizsgálatát is. A múben azonban nem esik szó a nominálbér, reálbér és vásárlóerő fogalmairól. A szakirodalom definíciója szerint, mint köztudott, a nominálbér az adózás előtti bruttó összeget jelenti, a reálbér az adózás utáni nettó összeget, a vásárlóerő pedig az egy pénzegységgel vagy egy meghatározott reálbérrel megvásárolható áruk és szolgáltatások mennyiségét fejezi ki. Ez a típusú megközelítés azonban figyelmen kívül hagy egy fontos elemet, ezért a reálbér definíciója nem teljesen fedi a valóságot. Ugyanis a reálbér tekintetében nem tesz különbséget az életben maradás és az élet megélése között. Valóban a reálbér azt az összeget képviseli, amit az alkalmazott ténylegesen elkölthet, de ennek az összegnek jelentős részét az életben maradásra költi, nem pedig az élet megélésére. Az életben maradáshoz, felszínen tartáshoz szükség van a házzal kapcsolatos kiadásokra (bérlés, részletfizetés), szükség van az energiahordozókkal járó kiadásokra (víz, gáz, villany) és természetesen az élelem költségeire. Ha csak ezek kifizetésére futja a reálbérből, akkor rabszolgatípusú életvitelről beszélhetünk. Ez eddig csak annyira elég, hogy egy ember élete ne legyen veszélyben vagy ne kerüljön a társadalom kiszorított, periferizált rétegéhez, de az emberhez méltó élet megélését az ezen felül járó költségek biztosítják. Ezek nagyon sokrétűek lehetnek: társadalmi kapcsolatokkal járó költségek, kulturális, szellemi, fizikai, lelki fejlődést, feltöltődést biztosító stb. költségek. Ezért az adózás után kézhez kapott reálbér lényegében pszeudoreálbér és ami az életben maradás érdekében kifizetett összeg után megmarad, az a valós reálbér. A társadalmi szerkezet/szerkezetek megfelelő megértése érdekében a háztartások osztályhelyzete, illetve státusz-, avagy identitáscsoportjai (etnikai, faji, vallási, ideológiai, szexuális preferenciájú stb.) is elemzésre kerülnek mint kikerülhetetlen jelentőségű elemek. (Wallerstein, 2010) Az elmélet rávilágít a modern állam kérdéskörére is és, ami a kapitalista berendezkedésnél még ennél is nagyobb jelentőséggel bír, az államok-vállalatok viszonyára. Az állam jól körülhatárolt szuverenitással felruházott hatalmi szerkezet. Nem titkolt tény, hogy ami sok esetben összetartja ezt a szerkezetet, az a nacionalista kötőelem, ezért egy külső ellenségkép kialakítása, ahogy George Orwell is kifejti, az állami hatalom megszilárdítását eredményezi. Sőt Machiavelli odáig megy, hogy kijelenti: „a szeretet nem, a gyülölet tart össze”. Wallerstein ezt a kérdéskört a szuverenitás fogalmával kezdi, majd a monarchikus szerkezeteket vizsgálja, ahonnan a jelenkori állami szerkezetek mikéntjére tér át. Kiemelendő, az abszolút monarchiában a törvény nem vonatkozik az uralkodóra, attól függetlenül, hogy ez nem feltétlenül jelent teljhatalmi szerepet. Itt megfigyelhetô egy párhuzam a kapitalizmussal, hiszen az utóbbinál a tulajdonjog az, amivel kivételeznek. A demokrácia, a jogegyenlőség a tôkés tulajdonán kívül esik. (Artner, 2014) Az állam-vállalat viszonyában a mú egyértelmúsíti, hogy az állami szuverenitás hét ponton érinti a vállalatok érdekeit: áru, tőke, munkaerő-áramlás, tulajdonjogrendszer, bérezési szabályozások, költségek internalizálásának meghatározása, monopolizálható ágazatok megjelölése 
és milyen mértékben, adózás, nyomásgyakorlás más államokra bizonyos kérdésekben. Wallerstein ugyanakkor rámutat egy olyan valóságra, amivel kevés szakirodalom foglalkozik, pedig jelentősége vitathatatlan. Ez a vállalati költségek externalizálása, ami azt jelenti, hogy vannak olyan költségek, amelyeket a vállalatok az állammal fizettetnek meg (szennyezéssel, erőforrásokkal és a szállítással járó költségek). A műből kitűnik a gyenge állam és erős állam fogalma is, az utóbbi köztudottan mindig a dominanciára törekedett és törekszik. Wallerstein azonban a dominancia megvalósítására két lehetőséget lát, és ezeket élesen elkülöníti egymástól. Az egyik a világgazdasági rendszer átalakítása világbirodalommá, a másik pedig a világrendszeren belüli hegemónia kialakítása. A világbirodalmakra jellemző, hogy egyetlen politikai autoritás uralja a világrendszert, ugyanakkor itt a katonai erő használata intenzív módon jelenik meg. Eddig a történelem folyamán az erre irányuló kísérletek mind elbuktak. Hegemóniáról viszont akkor beszélünk, amikor egy ország képes meghatározni az államközi rendszerek alapszabályait, uralni a világgazdaságot és érvényesíteni politikai akaratát, itt a katonai erő használata jóval kisebb mértékben jelentkezik, mint az első esetben. A hegemón státusz mindig átmeneti, történelmi időléptékkel mérve nem tart hosszú ideig. Az eddigi utolsó hegemón az Egyesült Államok. (Wallerstein, 2010) A mű két legfontosabb kérdése ugyanakkor itt fogalmazódik meg: miért nem volt lehetséges a világgazdaság világbirodalommá alakítása? Illetve a hegemónia miért nem tartott soha sokáig? Az előző kérdésre a válasz: mert a tőke vég nélküli felhalmozása, ami a kapitalizmus lényege, veszélybe kerülhet, hiszen a birodalmi szerkezetek e fölé emelkedhetnek. Az utóbbira pedig a válasz: ugyanazért, amiért a kvázimonopóliumok is rövid életúek, ugyanis idővel megjelennek más országok is, akik felzárkóznak és hasonló fejlettségű technológiákat kezdenek használni (termelésben, hadászatban, telekommunikációban, infrastruktúrában, erőforrásokban stb.), így a fölény lassan felszívódik. A geokultúra szempontjából az elmélet három fő területet jelöl, amely befolyással bírt és bír mai napig a világ dolgainak alakulásában, legfőképpen politikai szempontból. Az első az ideológiai küzdelem, amelynek mérföldköve a francia forradalom, és itt Wallerstein először a két fő politikai ideológiát elemzi. Az elemzés során kiderül, ezek honnan indultak, milyen változásokon mentek keresztül, és hol tartanak ma. A konzervatív erőket jobboldalinak ismerjük, akik 1879-ben és ezt követően a forradalmi eszme ellen léptek fel és a feudális rendszer visszaállítását sürgették azon meggyőződésüket kifejezve, hogy ez az egyetlen járható út. Ők az örökletes hierarchia, a patriarchális felépítés, a család és az egyház mellett tették le voksukat. A liberálisok esélyegyenlőséget hirdettek, meritokráciát, és úgy tartották, a természetes úton, az egyenlőség elvén létrejött hierarchia elfogadható, az örökletes pedig nem. Ugyancsak ők voltak azok, akik meghatározták a tudományágak fő irányvonalának eredőjét, és ezáltal hatásukra a humán tudományokról a hangsúly áttevődött a természettudományok oldalára. Egy vallásos társadalmi környezetben pedig azt hirdették, hogy a tudomány az alapja mindennek. Mindenképp a változás hívei voltak, de kiemelendő, hogy a fokozatos változásoké. Ez a centrumjellegű szemlélet volt, és nemritkán ők magukat a haladás pártjaként emlegették. A harmadik erő, amellyel bezárul az ideológiai kör, csak az 1848-as forradalmat követően jelent meg, ők pedig a radikálisok. Megjelenésük felbontotta a kétpólusú politikai palettát. A radikálisok, baloldali elhelyezéssel, a gyors és gyökeres változás hívei voltak, az eszközökben pedig közismert módon nem válogattak. A centrális erőt képviselő liberálisok 
a 19. és 20. század vezető ideológiájává váltak. A múben érdekes végigkísérni azokat a változásokat, amelyeken ezek az ideológiák végigmentek. A konzervatívok, akiket kezdetben csak a nemesi vérvonal érdekelt, hogyan váltak a nemzeti értékek védelmezőivé, a liberálisok, akik a „testvériség” védjegye alatt megerősítették a nemzet fogalmát, hogyan váltak a határok és a nemzetek visszaszorítóivá és leépítőivé. Ők a neoliberális eszme képviselőiként, a tôkeáramlás és szabad mozgás hívei lettek. A geokultúra második szempontja a rendszerellenesség. A rendszerellenes erők olyan csoportokat képviselnek, amelyeket szerintük kirekesztettek a hatalomból és ezáltal a döntéshozásból. Fontos megjegyezni róluk, hogy nem egy egységet alkotnak, hanem mély törésvonalak mentén képviselnek egy-egy „kirekesztett” csoportot, és mindegyik meggyőződése, hogy az általa képviselt csoport problémái a legégetőbbek. Ezért aztán egységes erőként soha nem is léptek fel, hiszen nemcsak a hatalom képviselőit bírálták, hanem egymással szemben is éles kritikákat fogalmaztak meg. Ők voltak a proletariátus, azaz munkásosztály, a nacionalisták és a nőmozgalmak képviselői. Ezen erők képviselői hosszú távú tervként először a hatalom átvételét, ezt követően programjuk megvalósítását tűzték ki célul, de amint a hatalomátvétel megtörtént (vagy részben megtörtént), érdekes módon nem a változást hozták el, hanem a meglévő hatalmi struktúrák konszolidálását eredményezték. A felháborodás társadalmi körökben ezért hatalmas volt, ami nagy részben hozzájárult az 1968-as forradalmi hullám kitöréséhez. A harmadik szempont a társadalomtudományok szerkezete és hovatartozása, de ezt az előző részekben már tárgyaltuk. Záróakkordként a modern világrendszer válságának kérdéskörét elemzi a szerző. Wallerstein meglátásában az a rendszer, amelyben ma élünk, már évtizedekkel ezelőtt válságba került, méghozzá az 1968-as forradalmi hullám kitörésekor, ezért azóta egy átmeneti állapot uralkodik. A szerző megteszi egyik, korunkat leginkább jellemző, legfontosabb kijelentését, miszerint a kapitalisták fő rejtett stabilizátora az elnyomottak optimizmusa. (Wallerstein, 2010) Ez az optimizmus veszett el 1968-ban. De az optimizmus mellett elveszett a liberális hatalom is. Helyét átvette a neoliberális eszmerendszer, amely nevezhető egy tőkekiszolgáló berendezkedésnek is. Ennek mérföldköve az 1989-ben megtartott „washingtoni konszenzus" néven ismertté vált konferencia, ahol a mai globalizáció „liberalizálj, deregulálj, privatizálj” fő irányelveit határozták meg. (Bogár, 2014) Az itt megfogalmazottak terjesztéséről az IMF és a WTO kezeskedett. Ennek ellenlépéseként ismert a Porto Alegre-i Társadalmi Világfórum. Ezt követően számos olyan országok, régiók, földrészek közötti (gazdasági, áruforgalmi, monetáris, energetikai stb.) együttmúködés jött létre, amelyet új regionalizmus néven ismerünk. 1970-tôl egyre inkább teret nyertek a gazdaságban a spekulatív tevékenységek a valós termeléssel szemben. Az azóta megjelenő számos aggasztó jelenség közül kiemelendő például a se nem dolgozó, se nem tanuló fiatal „ni-ni” nemzedékre keresztelt globális társadalmi réteg. (Artner, 2014) A szerző meglátásában a jövőben egyre gyakoribbak lesznek a szélsőséges kilengések és az erőszakkitörések. Wallerstein elméletében azonban arra nem tér ki, hogy a világ közelről sem annyira globális, mint azt képzeljük. Ma a világgazdaság sokkal kisebb mértékben integrált, mint az első világháború előtti korszakban. A globális világ részeként említhetjük mindössze az USA-t, EU-t és Ázsia bizonyos részeit. Ugyanakkor a jövő lehetőségeit fürkészve nem kerülhetjük meg az „új medievalizmus” elméletét, amely szerint várható, hogy eltünik az állami szuverenitás, és multinacionális vállalatok, nemzetközi szervek és NGO-k váltják fel az állam szerepeit. Ebben 
a megközelítésben a kormány és a kormányzás elválasztható. (Gilpin, 2004) Wallerstein végül müvében három előttünk álló feladatot jelöl ki, amely megoldásra vár a jövőben: a mostani helyzet megértése (intellektuális feladat, próbatétel), az irány meghatározása (erkölcsi feladat) és a lépések megtétele (politikai feladat).

\section{Összegzés}

Világunk sokrétű, egymással összefüggő elemeinek azonosítása, analízise és megértése elengedhetetlen a jövőbeni irányvonalak meghatározásában is. Wallerstein megfogalmazásában ez egy modern világrendszer, amely kapitalista világgazdaságként múködik. Ezen gazdaság legmeghatározóbb kerete a piac és egyik legfontosabb kelléke a tengelyszerű munkamegosztás, aminek következtében centrum-periféria viszony alakul ki az államok között. A centrumot az erős gazdaságok képviselik, a perifériát a gyengék, és e két szélső pont egymáshoz való viszonya határozza meg a globális világgazdaság müködését. Nem szabad ugyanakkor megfeledkeznünk a társadalmi rétegek fontosságáról, az osztályokról, státuszcsoportokról és az univerzalizmus, illetve antiuniverzalizmus ellentétéről és a politikai ideológiákról sem. A politikai és államokon belüli, illetve államközi viszonyok reális átlátása és jelenbeli, illetve jövőbeni kezelése szempontjából nem kerülhetjük meg a valós történelmi események feltárását úgy az idiografikus, mint a nomotetikus nézőpontok szerint. Mindezek összessége adja azt a mozaikszerú végleges képet, amellyel megérthetjük világunk tágabb értelemben vett múködését.

\section{Felhasznált irodalom}

Aronowitz, Stanley (1981): Crisis in Historical materialism: Class, Politics, and Culture in Marxist Theory. Praeger Publishers.

ARTner, Annamária (2014): Tőke, munka és válság a globalizáció korában. Budapest, Akadémiai Kiadó.

Brenner, Robert (1977): The Origins of Capitalist Development: A Critique of NeoSmithian Marxism. New Left Review, No. 104. 25-92.

GILPIN, Robert (2004): Nemzetközi politikai gazdaságtan. Budapest, BUCIPE Bt.

Hintze, Otto (1908): Historische und politische Aufsätze. 10 Volumes. Berlin, Deutsche Bücherei.

Machiavelli, Nicolò (2019): A fejedelem. Budapest, Helikon Kiadó Kft.

ORWELL, George (2019): Állatfarm. Budapest, Európa Könyvkiadó Kft.

SкостоL, Theda (1979): States and Social Revolutions. Cambridge, Cambridge University

Press. DOI: https://doi.org/10.1017/CBO9780511815805

Zolberg, Aristide (1966): Creating Political Order: One Party-States in West Africa. Chicago, Rand McNally \& Company.

WALlerstein, Immanuel (2010): Bevezetés a világrendszer-elméletbe. Budapest, L’Harmattan Kiadó. 
WIENER, György (2011): Wallerstein világrendszer-elméletének történetfelfogása. Eszmélet, 92. sz. 2011. 01. 01. Elérhető: www.eszmelet.hu/wiener_gyorgy-wallersteinvilagrendszer-elmeletenek-tortenet/ (A letöltés dátuma: 2020. 01. 26.)

\section{Internetes forrás}

BogÁR László (2014): Washingtoni konszenzus. Magyar Hírlap, Elérhető: www.magyarhirlap.hu/velemeny/Washingtoni_konszenzus (A letöltés dátuma: 2020. 01. 26.) 